\title{
NUTRITIONAL STATUS AND LIFE QUALITY IN PATIENTS UNDERGOING BARIATRIC SURGERY
}

\author{
Estado nutricional e qualidade de vida em pacientes submetidos à cirurgia bariátrica
}

Paulo Roberto Bezerra da SILVA, Marcela Ramos de SOUZA, Evane Moises da SILVA, Silvia Alves da SILVA

From the Curso de Nutrição do Centro Universitário do Vale do Ipojuca (Course of Nutrition of the Vale do Ipojuca University Center), Caruaru, PE, Brazil

HEADINGS - Obesity. Bariatric surgery. Adults.
ABSTRACT - Background: The obesity has achieved an alarming increase in recent years, which led this disease to global epidemic condition. Aim: To evaluate the nutritional status as well as the quality of life of obese patients undergoing bariatric surgery. Methods: A transversal study was conducted with obese adults of both genders who underwent bariatric surgery by FobiCapella technique for at least 30 days. It was evaluated: age, gender, marital status, occupation, weight before surgery, current weight, height, preoperative and current BMI, weight loss and loss of excess weight percentages, presence of clinical manifestations and food intolerances. Results: The sample consisted of 70 patients, being $81.4 \%$ female, $37.1 \%$ aged 30 to 39 years, $58.6 \%$ were married, $41.4 \%$ have undergone the bariatric surgery in the last 12 months. It was observed a reduction in BMI from $37.2 \mathrm{~kg} / \mathrm{m}^{2}$ (one to three months) to $28.9 \mathrm{~kg} / \mathrm{m}^{2}$ (>12 months) and consequent increase in weight loss and loss of excess weight percentages. The most frequent clinical manifestation was alopecia (62.9\%). The most reported food intolerance was on the red meat (24\%). According to the Baros questionnaire, $50 \%$ of patients were classified as having good quality of life. Conclusion: The operation of Fobi-Capella proved to be effective in promoting gradual and lasting weight loss. Quality of life was considered good in most patients, indicating that the operation had a positive impact on their lives.

\section{Correspondence:}

Paulo Roberto Bezerra da Silva

E-mail: robertogto@hotmail.com

Financial source: none

Conflicts of interest: none

Received for publication: 2/04/2014

Accepted for publication: 12/08/2014

DESCRTORES - Obesidade. Cirurgia bariátrica. Adultos.
RESUMO - Racional- A obesidade obteve aumento assustador nos últimos anos, levando essa doença à condição de epidemia global. Objetivo: Avaliar o estado nutricional, bem como a qualidade de vida de pacientes obesos submetidos à cirurgia bariátrica. Método: Estudo transversal realizado em obesos adultos de ambos os sexos que se submeteram à cirurgia bariátrica por técnica de Fobi-Capella há pelo menos 30 dias. Foram avaliados: idade, sexo, estado civil, profissão, peso anterior à operação, peso atual, altura, índice de massa corpórea pré-operatório e atual, porcentagem de perda ponderal e porcentagem de perda do excesso de peso, manifestações clínicas e presença de intolerâncias alimentares. Resultados: A amostra foi constituída de 70 pacientes, sendo $81,4 \%$ do sexo feminino, $37,1 \%$ na faixa etária entre 30 a 39 anos, $58,6 \%$ casados, $41,4 \%$ com $>12$ meses de cirurgia bariátrica. Observou-se redução do índice de massa corpórea de $37,2 \mathrm{~kg} / \mathrm{m}^{2}$ (um a três meses) para $28,9 \mathrm{~kg} / \mathrm{m}^{2}$ (>12 meses) e consequente aumento da porcentagem de perda ponderal e da perda do excesso de peso. A manifestação clínica mais frequente foi alopecia (62,9\%). A intolerância alimentar mais relatada foi em relação à carne vermelha (24\%). De acordo com o questionário Baros, $50 \%$ dos pacientes foram classificados como tendo boa qualidade de vida. Conclusão: A operação de Fobi-Capella mostrou-se efetiva em promover perda ponderal gradual. A qualidade de vida foi considerada boa na maior parte dos pacientes, indicando que a operação tem impacto positivo na vida desses pacientes.

INTRODUCTION

A ccording to the World Health Organization ${ }^{27}$, obesity is a noncommunicable chronic illness characterized by excess of the body fat causing damage to health. With its increase, in recent years was considered a condition of global epidemy ${ }^{5}$.

Surveillance of risk factors and protection for chronic diseases made by phone inquiring ${ }^{13}$ showed that obesity presents prevalence around $15.5 \%$ for women and $14.4 \%$ for men. In this way, the current scenario of obesity in Brazil is 30 million people and 600 million in the world population, according to the Brazilian Society of Bariatric and Metabolic Surgery 22

One of the criteria for diagnosing obesity is the body mass index (BMI), being calculated by body weight in kilograms and height in square meters ${ }^{25}$; are considered as obese the person with a BMI equal or superior than $30 \mathrm{~kg} / \mathrm{m}^{2}$ and morbid obesity with equal or superior than $40 \mathrm{~kg} / \mathrm{m}^{2}$. At this stage can exist co-morbidities, such as diabetes mellitus type 2, hypertension, congestive heart failure, hyperlipidemia and atherosclerosis, contributing to higher mortality from cardiovascular diseases and other pathological complications, reducing the quality of life $17,18,29$.

The cause of obesity is multifactorial; can occurforendocrine, metabolic, genetic, 
psychological and environmental amendments ${ }^{18}$. For the weight reduction, dietary guidance, physical activity and the use of anti-obesity drugs can be successfull in short period of time ${ }^{9}$. Bariatric surgery is an option for people with morbid obesity who cannot lose weight by traditional methods ${ }^{12}$

Due to failures on the conservative methods, the literature emphasizes several surgical procedures for weight reduction with long-term efficacy. Several techniques are being used reducing the size of the stomach - limiting food intake - or by restricting the gastric capacity, or by its division with proximal jejunal anastomosis ${ }^{10}$. The indication should be based on several clinical aspects, assessed by a multidisciplinary team; the nutritional criteria is presence of BMI superior or equal to $40 \mathrm{~kg} / \mathrm{m}^{2}$ or BMI exceeding $35 \mathrm{~kg} /$ $\mathrm{m}^{2}$ associated with comorbidities, according to the Brazilian Federal Council of Medicine ${ }^{3}$. Brazilian resolution CFM N $\mathrm{N}^{\circ} 1.766 / 05^{3}$ surgery is contraindicated in subjects with severe renal failure, lung diseases, myocardial damage and cirrhosis of the liver.

For the surgical treatment of obesity restrictive, disabsortive or mixed techniques may be used. Purely restrictive ones act on the stomach, shrinking its size and causing reduction in food consumption. Others include vertical gastroplasty, adjustable elastic bands and intragastric balloon ${ }^{1}$. The disabsortive act only in the intestine, with a technique called bilio-pancreatic derivation and duodenal transposition, resulting in loss of weight by limiting nutrient absorption ${ }^{6}$. Mixed operations promote early satiety, where gastric bypass is associated to gastrojejunal derivation in $\mathrm{Y}$-ofRoux - Fobi-Capella technique - decreasing the volume of the stomach to $30 \mathrm{ml}^{7}$.

Some postoperative nutritional complications protein malnutrition, deficiency of vitamins and minerals -, occur due to reduced food consumption and lower absorption of nutrients ${ }^{23}$. Clinical studies show that, after the operation, there is rapid weight loss that extends from 18 to 24 months after the procedure and can keep $50-60 \%$ of the loss of excess weight by up to 10 to 14 years ${ }^{21}$. In addition to weight loss, individuals who have undergone bariatric surgery showed changes in lifestyle and improvements in quality of life in physical, psychological and social relationship ${ }^{11}$.

This study aimed to assess the nutritional status and the quality of life of obese patients undergoing bariatric surgery.

\section{METHODS}

The research was approved by the Research Ethics Committee of the College of Vale do Ipojuca, Protocol $00080 / 2012$. All participants have authorized the study and signed an informed consent. It was descriptive transverse type research done a private clinic in the city of Caruaru, PE, Brazil. Obese were of both genders aged 18-59 years, who underwent the operation of FobiCapella. Were excluded patients with psychiatric disorders and pregnant women.

The data collection was realized from August to September 2012, through individual interview applying a questionnaire specially prepared containing the following variables: age, sex, marital status, occupation, time of surgery, weight prior to the operation, current weight, height, pre-surgery BMI and current one, percentage of weight loss, loss of weight excess, clinical manifestations and presence of food intolerances.

To the anthropometric evaluation (weight and height) patients used scales with capacity of $150 \mathrm{~kg}$ and precision of $100 \mathrm{~g}$. The obesity classification and BMI was calculated as stipulated by the World Health Organization ${ }^{26}$ using the following equation: body weight in kilograms by the square of height in meters ${ }^{26}$.

To determine the weight loss was followed the WHO 2007 guidance 28 for the calculation of the percentage of loss of weight (PP\%) and for loss of excess weight.

For the evaluation of quality of life after the operation was applied a questionnaire elaborated by Oria and Moorehead ${ }^{17}$ (Bariatric Analysis and Reporting Outcome System - Baros), which includes questions about self-esteem, physical status, sociability, ability to work and/ or study, sexual performance, percentage of excess weight loss and displeasure with side effect and complications of the operation.

According to the responses obtained, the quality of life was ranked: insufficient ( 1 point $<$ ), acceptable ( 1 to 3 points), good ( $>3$ to 5 points), very good (> 5 until 7 points) and excellent (> 7 to 9 points).

The data obtained were processed and analyzed by Microsoft Exce ${ }^{\circledR}$ version 2007. Continuous variables were demonstrated in averages and standard deviation and the categorical in numerical and percentage frequency.

\section{RESULTS}

The sample was composed of 70 patients. Table 1 shows the general characteristics, where it can be seen predominance of female, age between 30 and 39, married status and mostly liberal professionals. Respondents had in greater proportion exceeded 12 months post-surgery period.

TABLE 1 - Characterization of obese patients undergoing FobiCapella operation

\begin{tabular}{|l|c|c|}
\hline $\begin{array}{l}\text { Variables } \\
\text { Gender } \\
\text { Masculine }\end{array}$ & N & $\%$ \\
\hline $\begin{array}{l}\text { Feminine } \\
\text { Age group (year) }\end{array}$ & 13 & 18,6 \\
\hline $\begin{array}{l}19 \text { to } 29 \\
30 \text { to } 39\end{array}$ & 16 & 21,4 \\
\hline 40 to 49 & 26 & 37,1 \\
\hline $\mathbf{5 0}$ & 22 & 31,4 \\
\hline Marital status & 6 & 8,6 \\
\hline Single & & \\
\hline Married & 25 & 35,7 \\
\hline Divorced/ Widowed & 41 & 58,6 \\
\hline Professional activities & 4 & 5,7 \\
\hline Student & & \\
\hline Free Lance & 2 & 2,9 \\
\hline Formal professional & 35 & 50 \\
\hline Time of surgery (months) & 33 & 47,1 \\
\hline 1 to 6 & & \\
\hline 7 to 12 & 26 & 37,2 \\
\hline$>12$ & 15 & 21,4 \\
\hline
\end{tabular}

Table 2 presents the anthropometric parameters according to the postoperative periods. Can be observed significant BMI reduction, as well as gradual increase in the percentage of loss of weight and percentage of excess weight loss over time. 
TABLE 2- Average and standard deviation distribution of the variables BMI, PP and PEP according to postoperative periods of the obese submitted to Fobi-Capella surgery

\begin{tabular}{|c|c|c|c|c|c|}
\hline \multirow{3}{*}{ VARIABLES } & \multicolumn{4}{|c|}{ POSTOPERATIVE PERIODS } & \multirow{3}{*}{$p^{*}$} \\
\hline & 1 a $3 m$ & 4 a $6 m$ & 7 a $12 m$ & $>12 \mathrm{~m}$ & \\
\hline & (n) $M \pm D P$ & (n) $M \pm D P$ & (n) $M \pm D P$ & (n) $M \pm D P$ & \\
\hline BMI & $\begin{array}{c}(19) \\
37,2 \pm 5,1\end{array}$ & $\begin{array}{c}(7) \\
35,7 \pm 9,9\end{array}$ & $\begin{array}{c}(15) \\
30,2 \pm 4,6\end{array}$ & $\begin{array}{c}(29) \\
28,9 \pm 4,4\end{array}$ & 0,00 \\
\hline PP\% & $\begin{array}{c}(19) \\
13,8 \pm 3,4\end{array}$ & $\begin{array}{c}(7) \\
26,6 \pm 4,9\end{array}$ & $\begin{array}{c}(15) \\
33,6 \pm 3,6\end{array}$ & $\begin{array}{c}(29) \\
36,3 \pm 9,2\end{array}$ & $0,0 c$ \\
\hline PEP\% & $\begin{array}{c}(19) \\
31,9 \pm 12,2\end{array}$ & $\begin{array}{c}(7) \\
59,7 \pm 18,8\end{array}$ & $\begin{array}{c}(15) \\
77,6 \pm 14,2\end{array}$ & $\begin{array}{c}(29) \\
81,1 \pm 20,6\end{array}$ & 0,000 \\
\hline
\end{tabular}

${ }^{*} \mathrm{ANOVA} ; \mathrm{BMI}=$ body mass index; $\mathrm{PP} \%=$ percentage of weight loss; $\mathrm{PEP} \%=$ percentage of excess weight loss

Hair loss and vomiting were the more prevalent clinical signs after the operation (Figure 1).

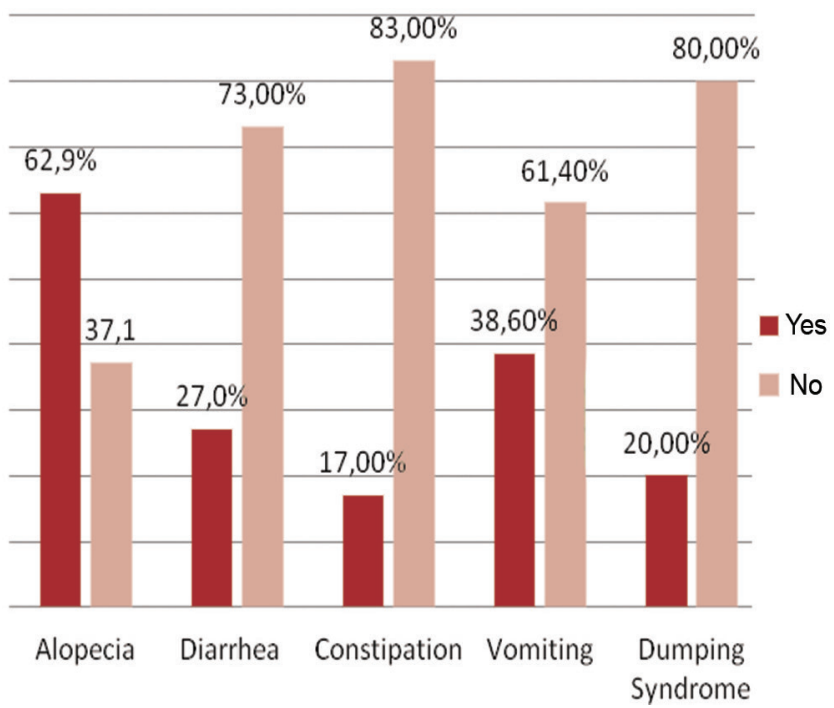

FIGURE 1 - Frequency of clinical manifestations in the FobiCapella postoperative period

After the operation, the more mentioned intolerances were to meats, sweets and fried foods (Figure 2)

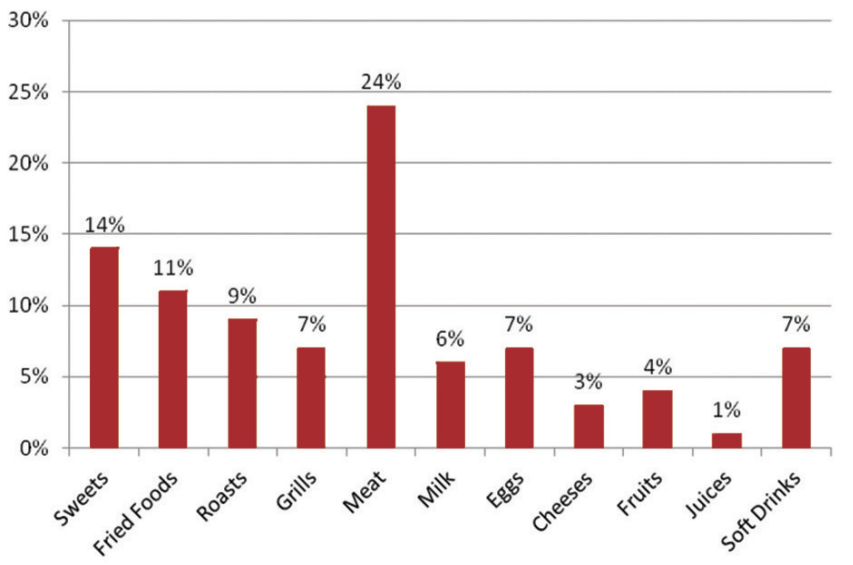

FIGURE 2 - Intolerance to specific foods in postoperative period of Fobi-Capella operation

The evaluation of the degree of life quality through Baros' questionnaire, showed largest proportion of patients classified as good. Were observed few ones insufficient and none with excellent quality (Figure 3).

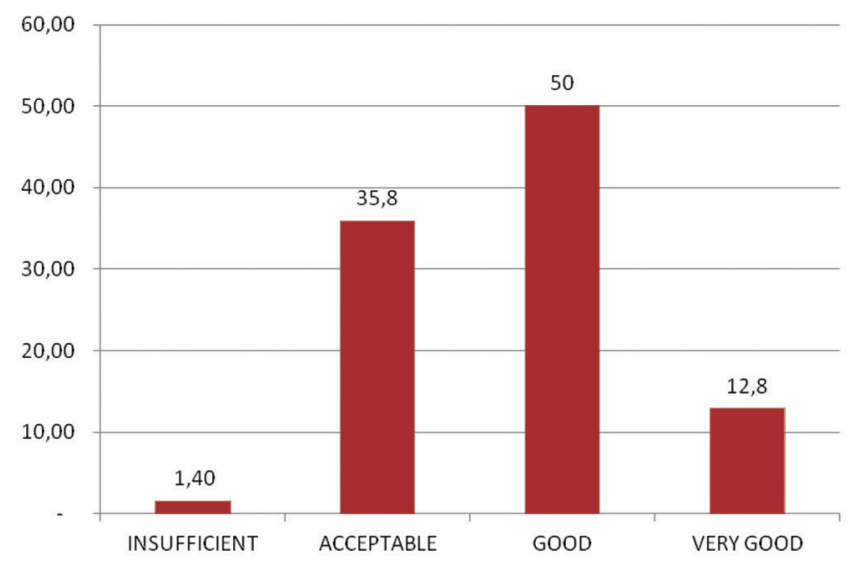

FIGURE 3 - Baros quality of life in patients undergoing FobiCapella operation

\section{DISCUSSION}

In this research women numerically predominated. These result is similar to Ferraz et $\mathrm{al}^{8}$, and is justified by beauty standards imposed by current society. The age group between 30 and 39 years is in agreement with others ${ }^{2}$. The patients reachedsatisfactoryweightlossand, above 12 months of follow-up, had BMI compatible with overweight and no more with obesity. Santos et $\mathrm{al}^{20}$ observed gradual elevation of the percentage of weight loss and loss of weight excess, showing the effectiveness of the operation.

The hair loss was the most common manifestation, followed by vomiting and diarrhea. According to Mafra and Cozzolino ${ }^{14}$, hair loss can be attributed to zinc deficiency, protein and essential fatty acids. Moltin ${ }^{15}$ says that vomiting is consequence of fatty foods and concentrated sweets ingestion, insufficient chewing, eating too much or fast feeding. The diarrhea can be explained by the excessive consume of simple carbohydrates (dumping syndrome) and fatty foods, due to the exclusion of the duodenum and most of the proximal jejunum; it can be softened by dietary control and dietary reeducation post-surgery ${ }^{18,19}$.

Specific food intolerance may develop after stomach reduction operations. Intolerance to red meat was more frequent, followed by sweets ${ }^{1}$. The the meat intolerance is expected due to the partial gastrectomy with its consequent alteration in the production of pepsin, primarily responsible for proteins digestion ${ }^{2}$. Among the clinical symptoms, the dumping syndrome was very characteristic on Fobi-Capella technique, which has arisen due to the rapid gastric emptying occurring mainly after ingestion of simple carbohydrates ${ }^{7,30}$.

In this research, most of the patients were classified as having good quality of life and none with excellent showing to be effective on it. Faria et $\mathrm{al}^{4}$, regarding the evaluation of surgical success by Baros, showed $89 \%$ of patients favorable with the surgical intervention, since there was an improvement in selfesteem, sociability, physical conditions, willingness to work, libido, weight loss and comorbidities.

CONCLUSION

The operation of Fobi-Capella proved to be effective in promoting gradual and lasting weight loss. Quality of life was considered good in most patients, indicating that the operation had a positive impact on their lives. 
REFERENCES

1. Bregion NO, Silva AS, Salvo VLMA. Estado nutricional e condição de saúde de pacientes nos períodos pré e pós-operatório de cirurgia bariátrica. RBCS 2007 out /dez; 3(14):33-42.

2. Kenler HA, Brolin RE, Cody RP. Changes in eat behavior after horizontal gastroplastyand Roux-en-Y gastric bypass. Am J Clin Nutr. 1990;52(1):87-92.

3. CFM. 2005. Conselho Federal de Medicina. Disponível em: http:// www.portalmedico.org.br/resolucoes/cfm/2010/1942_2010.htm. Acesso em 15 de abril de 2012 às, 22:40h.

4. Faria O, Pereira VA, Gangoni CMC, Lins RD, Leite $S$, Rassi V, et al. Obesos mórbidos tratados com gastroplastia redutora com bypass gástrico em y de roux: análise de 160 pacientes. Brasília Méd 2002;39:26-34

5. Francischi RPP, Pereira LO, Freitas CS, Klopfer M, Santos RC, Vieira $P$, et al. Obesidade: atualização sobre sua etiologia, morbidade e tratamento. Rev Nut 2000 jan/abr;13(1):17-28.

6. Faintuch J, Oliveira CPMS, Rascovski A, Matsuda M, Brescian CJC; Cruz MELF, et al. Considerações nutricionais sobre a cirurgia bariátrica. Rev Bras Nutr Clin 2003; 18(3):07-09.

7. Fandiño J, Benchiomol AK, Coutinho WF, Appolinário JC. Cirurgia bariátrica: aspectos clínico-cirúrgicos e psiquiátricos. R. psiquiatr 2004 jan/abr; 26(1): 47-51

8. Ferraz AA, Albuquerque AC. Tratamento cirúrgico da obesidade mórbida. Rev Col Bras 2003; 30(2):98-105.

9. GelonezeB, ParejaJC.Cirurgiabariátricacuraasíndromemetabólica? Arq Bras Endocrinol Metab 2006 abr; 50(2): 400-407.

10. Garrido júnior $A B$. cirurgia em obesos mórbidos- experiência pessoa. Arq. Bras. Endocrinol Metab 2000; 44(1):106-113.

11. Lemos MCM. Qualidade de vida de pacientes submetidos a cirurgia bariátrica no município de cascavel. Arq Ciên Saúde 2006;10:155-163.

12. Marcelino LF, Patrício ZM. A complexidade da obesidade e o processo de viver após a cirurgia bariátrica: uma questão de saúde coletiva. Ciências e Saúde Coletiva. 2011;16: (12):4767-4776.

13. Ministério da saúde (Brasil). Vigilância de Fatores de risco para Doenças Crônicas por inquérito Telefônico. Brasília: ministério da saúde; 2011; 153 p.

14. Mafra D, Cozzolino SMF. Importância do zinco na nutrição humana. RNC 2004; jan./mar 17(1):79-87.

15. Mottin CC, et al. Tolerância alimentar no acompanhamento pósoperatório da cirurgia bariátrica: um estudo de 149 pacientes obesos mórbidos. Bol Cirurgia da Obes 2002; 3(3):45.
16. Nassif PAN, Malafaia O, Ribas CAPM, Pachnicki JPA, Kume $\mathrm{MH}$, MacedoLM, RikimaruTA. Estudodacorrelaçãodoimcecomprimento do intestino delgado em pacientes obesos submetidos à cirurgia bariátrica. ABCD Arq Bras Cir Dig 2009;22(3):153-7.

17. Oria HE, Moorehead MK. Bariatric analysis and reporting outcome system (BAROS). Obes Surg 1998;8 (5): 487-499.

18. Prevedello CF, Colpo E, Mayer ET, Copetti H. Análise do impacto da cirurgia bariátrica em uma população do centro do estado do Rio Grande do Sul utilizando método BAROS; Arq gastroenterol.2009; 46(3): 199-203.

19. Quadros MRR, Savaris AL, Ferreira MV, Branco-Filho AJ. Intolerância alimentar no pós-operatório de pacientes submetidos a cirurgia bariátrica. Rev Bras Nutr Clin. 2007; 22:15-9.

20. Santos EMC, Burgus MGP, Silva SA. Perda ponderal após cirurgia bariátrica de Fobi-Capella: realidade de um hospital universitário do nordeste brasileiro Rev Bras Nutr Clin ; 2006; 21(3):188-92.

21. Segal $A$, Fandino J. Indicação e contra-indicação para realização das operações bariátricas. Rev. Bras. Psiquiatr. 2002; 24: 68-71.

22. Sociedade Brasileira De Cirurgia Bariátrica (SBCB) [periódicos na internet]. 2012 abril [Acesso em 15 de abril de 2012]. Disponível em: http://www.sbcb.org.br

23. Silva AS, Burgos MGPA, Santos EMC, Batista JEM, Bion FM. Consumo alimentar de obesos em períodos pré e pós-operatórios de cirurgia bariátrica. An. Fac. Med. Univ. Fed.Pernamb.2005; 50(1):15-18.

24. World Health Organization (WHO). Obesity in Europe. 2012; [acesso em de maio de 2012 ás, 23:30h] Disponível em http://www. euro.who.int/en/what-we-do/health-topics/noncommunicablediseases/obesity

25. World Health Organization (WHO). Obesity: preventing hand managing the global epidemic: report of a WHO consultation.2000; Geneva, Switzerland.

26. World Health Organization (WHO). Obesity: preventing hand managing the global epidemic: report of a WHO consultation.1997; Geneva, Switzerland.

27. World Health Organization (WHO). Obesity: preventing hand managing the global epidemic: report of a WHO consultation.2006; Geneva, Switzerland.

28. World Health Organization (WHO). Obesity: preventing hand managing the global epidemic: report of a WHO consultation.2007; Geneva, Switzerland

29. World Health Organization (WHO). Diet, nutrition andprevention of chronic diseases. Report of a Joint WHO/FAO Expert Consultation. Geneva: WHO; 2003. WHO Technical Report Series, 916.

30. Loss AB, Souza AAPS, Pitombo CA, Milcent M, Madureira FAV. Avaliação da síndrome de dumping em pacientes obesos mórbidos submetidos à operação de bypassgástrico com reconstrução em Y de Roux. Rev. Col. Bras. Cir. 2009; 36(5): 413-419. 